\title{
УДК: 612.017+613.6:546.3
}

\section{СТАН ІМУННОї СИСТЕМИ У ПРАЩЮЮЧИХ, EКСПОНОВАНИХ СвИНUЕМ}

\author{
Амитруха Н.М., Короленко Т.К., АнАрусишина І.М.
}

\section{Інститут меАишини праші АМН України, м.Київ}

У роботі представлено результати обстеження працівників заводу художнього скла, експонованих свинцем. За даними біомоніторингу, вміст катіонів свинцю в крові обстежених перевищував нормативні значення. В осіб з діагнозом хронічна свинцева інтоксикація $(\mathrm{Pb}-0,59 \pm 0,07$ мг/л) спостерігалися порушення майже всіх клітинних та гуморальних показників імунного статусу, які корелювали з концентрацією свинцю в крові. У працюючих з вмістом свинцю на рівні $0,44 \pm 0,08$ мг/л, без ознак інтоксикації виявлені зміни були схожі за спрямованістю, проте менш вираженими.

Ключові слова: імунна система, свинець, інтоксикація

\section{Ветуп}

Свинець належить до токсичних, високо кумулятивних отрут з політропною дією на організм [28, 29]. 3 літератури відомо, що при інтоксикації цим металом у людини порушується процес кровотворення, уражаються центральна і периферична нервова система, шлунково-кишковий тракт, нирки, судини тощо $[6,16,27]$. В окремих роботах висвітлено імуномодулюючу дію свинцю, показано, що в малих дозах він викликає стимуляцію показників неспецифічної резистентності, тоді як великі концентрації його, навпаки, виявляють пригнічувальний ефект $[3,7,8,13,26]$. Слід зауважити, що дані стосовно визначення імунологічної реактивності організму людей, які підпадають експозиції свинцем у виробничих умовах, досить обмежені.

Імунна система є однією з найважливіших гомеостатичних систем організму. Вона визначає загальний стан здоров'я людини та її адаптаційні можливості. Зниження імунологічної реактивності організму внаслідок негативної дії чинників оточуючого середовища призводить до підвищення частоти інфекційних, алергічних, онкологічних та інших захворювань [7, 31]. Отже, вивчення змін імунного статусу людей, контактуючих з токсичними речовинами, в тому числі і з важкими металами, є актуальною медико-біологічною проблемою.

Метою роботи було дослідження стану імунної системи організму працівників заводу художнього скла, експонованих свинцем в умовах виробництва.

\section{Матеріали та методи дослідження}

Дослідження проведено на заводі з виготовлення художнього скла (3ХС), де за технологічною схемою для отримання кришталю використовують оксиди свинцю - свинцевий сурик $\left(\mathrm{Pb}_{3} \mathrm{O}_{4}\right)$ і свинцевий глет $(\mathrm{PbO})$. Загалом кришталь залежно від сорту може містити від $9 \%$ до $37 \%$ окисів свинцю. В умовах виробництва кришталю свинець у вигляді аерозолю може надходити до повітря робочої зони та створювати небезпеку для здоров'я працюючих.

Дослідження стану імунологічної реактивності організму проведено в двох групах працівників 3ХС. Перша група -10 робітників, середній вік $38,2 \pm 1,3$, які були експоновані свинцем (ЕС), але не мали ознак інтоксикації; друга група - 12 осіб, середній вік 41,3 \pm 1,2, з клінічно встановленим діагнозом хронічна свинцева інтоксикація (XCI). Қонтрольну групу становили 10 викладачів, віком 39-41 рік, які професійно не контактували з важкими металами.

Під час обстеження проведено загальний аналіз крові з визначенням гемоглобіну, кількості еритроцитів, лейкоцитів та іх популяційного складу за стандартними гематологічними методами [21]. Для дослідження стану імунної системи у працюючих було взято показники, що характеризують неспецифічну резистентність організму: фагоцитарна активність нейтрофілів крові (фагоцитарний індекс Ф) та фагоцитарне число - ФЧ), бактерицидна здатність фагоцитів (НСТ-спонтанний та НСТ-стимульований) [20], титр комплемента в сироватці крові за 50\% гемолізом еритроцитів барана [18]. Для оцінки клітинної та гуморальної ланок імунного статусу визначали загальну кількість Т- та Влімфоцитів в реакції розеткоутворення з еритроцитами барана та миші, Т-хелперів і Т-супресорів за чутливістю до теофіліну [20], рівень IgG, IgM, IgA за Манчіні $[2,20]$ та циркулюючих імунних комплексів у сироватці крові методом преципітації з поліетиленгліколем $M=6000$ [20]. 
На виробництві було проведено санітарно-гігієнічні дослідження з визначенням параметрів мікроклімату (температура, вологість повітря) та фізичних чинників (шум, вібрація) [22]. Вміст свинцю у повітрі робочої зони та у крові обстежених осіб визначали за методом атомно-абсорбційної спектроскопії (AАC) на приладі «Сатурн-III» П1 [4, 15].

Результати дослідження обчислено статистично на комп'ютері за допомогою стандартного пакету програм Excel з визначенням середніх величин та їхніх похибок $(M \pm \mathrm{m})$, показника достовірності (t-критерія Ст'юдента), коефіцієнта кореляційної залежності (r) [14].

\section{Результати дослідження та їх обговорення}

За технологічною схемою процес виготовлення скла розподіляється на такі етапи:

- підготовка сировини та змішування шихти;

- подача шихти у скловарну піч;

- набір скломаси та видув виробів;

- шліфування готових виробів.

Проведені санітарно-гігієнічні дослідження засвідчили, що мікрокліматичні параметри виробничого середовища заводу художнього скла перебували в межах допустимих значень (температура повітря $21-22^{\circ} \mathrm{C}$, відносна вологість $75 \%$ ). Еквівалентні рівні шуму в цеху становили $77-78$ дБА, що не перевищувало ГДР.

Аналіз відібраних проб повітря засвідчив, що додавання до скломаси оксидів свинцю призводило до збільшення концентрації цього металу у виробничій зоні при змішуванні шихти, видуванні та шліфуванні виробів (табл. 1).

Таким чином, умови праці призводили до експозиції робітників аерозолем свинцю, вміст якого у повітрі робочої зони на всіх технологічних етапах був значно вищим за ГДК.

За результатами біологічного моніторингу встановлено, що у групі працівників заводу, які не мали ознак свинцевої інтоксикації, концентрація металу у крові була в середньому $0,44 \pm 0,08$ мг/л, а в осіб 3 клінічним діагнозом XCI $-0,59 \pm 0,07 \mathrm{мг} / л$, шо перевищувало дані в контрольній групі $(0,32 \pm$ $0,06 \mathrm{мг} / л)$ та норми ВООЗ (0,2-0,4 мг/л).

Загальний аналіз крові в обстежених працівників 3ХС засвідчив підвищену кількість моноцитів, еозинофілів та ШОЕ у пацієнтів з ХCI, в них також було виявлено збільшену кількість еритроцитів 3 базофільною зернистістю, що розглядаються як одна зі специфічних ознак свинцевої інтоксикації. У групі ЕС робітників спостерігали тільки підвищення кількості лейкоцитів. Вміст інших клітинних елементів крові в обох групах не відрізнявся від контролю (табл. 2).

Під час дослідження імунологічної реактивності організму в обстежених групах працівників 3ХC було виявлено низку змін (табл. 3 ).

У працівників ЕС відсоток нейтрофілів, що беруть участь у фагоцитозі, був на рівні контрольних значень, тоді як фагоцитарне число збільшувалося, спостерігалася також стимуляція окисно-відновних процесів у цих клітинах за НСТ-тестом. Кількісне розподілення Т- та В-лімфоцитів у цій групі не відрізнялося від контролю, проте кількість Т-хелперів зростала, а Т-супресорів - знижувалася, відповідно зростав імунорегуляторний індекс ( $\mathrm{Tx} / \mathrm{Tc})$. Визначався підвищений вміст IgM та циркулюючих імунних комплексів (ЦК) у сироватці крові (Р < 0,05 щодо контролю).

У пацієнтів з діагнозом XCI відмічали стимуляцію фагоцитарної та метаболічної активності нейтрофілів разом із зростанням титру комплемента в сироватці крові. Відносна кількість Т - та В-лімфоцитів у них істотно не змінювалася, тоді як кількість Т-хелперів вірогідно збільшувалася, а Т-супресорів, навпаки, - знижувалася, зростав також імунорегуляторний індекс, відповідь лімфоцитів на мітоген ФГА була пригніченою. Інтоксикація свинцем викликала підвищення функціональної активності

Вміст пилу та свинцю на робочому місці працівників заводу художнього скла

\begin{tabular}{|c|c|c|}
\hline \multirow{2}{*}{$\begin{array}{c}\text { Цех, } \\
\text { робоче місце }\end{array}$} & \multicolumn{2}{|c|}{ Концентрація, мг/м³ } \\
\hline & Пил загальний & Свинець \\
\hline ГДК & 10 & $0,01 / 0,005$ \\
\hline Змішування шихти & $4,47 \pm 0,40$ & $0,12 \pm 0,045$ \\
\hline Цех №1, видувальник & $2,82 \pm 0,32$ & $0,13 \pm 0,028$ \\
\hline Цех №1, шліфувальник & $12,30 \pm 3,39$ & $0,15 \pm 0,039$ \\
\hline Цех №2, видувальник & $3,22 \pm 1,02$ & $0,085 \pm 0,005$ \\
\hline Цех №2, шліфувальник & $19,90 \pm 2,71$ & $0,12 \pm 0,02$ \\
\hline На території заводу & $2,30 \pm 0,81$ & $0,03 \pm 0,004$ \\
\hline
\end{tabular}


Показники периферичної крові у.працівників заводу художнього скла,

експонованих свинцем, $(M \pm \mathrm{m})$

\begin{tabular}{|l|c|c|c|}
\hline & Контрольна група & Працівники ЕС & Працівники з ХСІ \\
\hline Еритроцити, 1·1012/л & $4,1 \pm 0,1$ & $4,4 \pm 0,1$ & $4,4 \pm 0,1$ \\
\hline Еритроцити 3 базофільною зернистістю, \% & $2,1 \pm 0,8$ & $4,0 \pm 0,9$ & $7,1 \pm 1,0^{*}$ \\
\hline Гемоглобін, г/л & $135,3 \pm 3,5$ & $135,3 \pm 2,7$ & $132,8 \pm 2,7$ \\
\hline Лейкоцити, 1·10\%/л & $5,9 \pm 0,2$ & $8,3 \pm 0,8^{*}$ & $6,8 \pm 0,4$ \\
\hline Лімфоцити, \% & $36,4 \pm 1,5$ & $34,2 \pm 2,2$ & $32,8 \pm 2,6$ \\
\hline Нейтрофіли п/я, \% & $1,5 \pm 0,2$ & $1,3 \pm 0,2$ & $1,4 \pm 0,2$ \\
\hline Нейтрофіли с/я, \% & $52,8 \pm 1,0$ & $56,3 \pm 3,0$ & $55,5 \pm 1,8$ \\
\hline Моноцити, \% & $4,7 \pm 0,6$ & $5,6 \pm 1,0$ & $6,8 \pm 0,9^{*}$ \\
\hline Еозинофіли, \% & $2,9 \pm 0,7$ & $1,6 \pm 0,3$ & $3,6 \pm 0,6^{*}$ \\
\hline ШОЕ, мм/г & $4,5 \pm 0,5$ & $5,7 \pm 1,1$ & $7,3 \pm 1,7 *$ \\
\hline
\end{tabular}

Примітка. Утабл. 2, 3: * - вірогідно щодо контролю $(P<0,05)$.

В-клітин, внаслідок чого вірогідно щодо контролю $(\mathrm{P}<0,05)$ зростали концентрація сироваткових IgM, IgG, IgA та ЦІК.

Отримані результати дослідження засвідчили, що експозиція працюючих свинцем, як в осіб без ознак інтоксикації, так і при встановленій хронічній свинцевій інтоксикації викликала зміни показників, що характеризують неспецифічну резистентність та імунологічну реактивність організму.

Виявлені зміни кореспондували з даними літератури про те, що контакт зі свинцем в умовах виробництва може викликати у працюючих пригнічення показниќів неспецифічної резистентності та формування вторинного імунодефіциту [1, 9, 24, 33]. У робітників, експонованих свинцем, з рівнем його у крові 0,3-0,9 мг/л виявлено порушення супресорної функції Т-клітин [9], пригнічення проліферативної активності лімфоцитів крові на мітогени in vitro $[10,19]$. В осіб з рівнем свинцю в крові 0,38 мг/л встановлено зниження фагоцитарної активності нейтрофілів, тоді як рівень сироваткових $\operatorname{IgG}, \operatorname{Ig} M$, IgA не змінювався щодо контролю, де вміст свинцю був $0,12 \mathrm{мг/л[11].}$

Під час обстеження дітей, які мешкали у промисловому районі (серед токсикантів був і свинець), відсоток НСТ-позитивних нейтрофілів виявився у 1,7-2 рази вищим за контрольні дані, що, на думку авторів [17], свідчить про напруження метаболічної активності фагоцитів та підвищення серед обстежених частоти інфекційних захворювань.

Таблищя 3

Показники імунного статусу організму працівників заводу художнього скла, експонованих свинцем, $(M \pm \mathrm{m})$

\begin{tabular}{|c|c|c|c|}
\hline Показники & Контрольна група & Працівники ЕС & Працівники 3 XСI \\
\hline $\mathrm{Pb}$ у крові, мг/л & $0,32 \pm 0,06$ & $0,44 \pm 0,08$ & $0,59 \pm 0,07^{*}$ \\
\hline$\Phi \mathrm{I}, \%$ & $64,7 \pm 1,8$ & $62,0 \pm 1,9$ & $74,9 \pm 2,3^{*}$ \\
\hline ФЧ, ум.од. & $3,6 \pm 0,2$ & $5,6 \pm 0,3^{*}$ & $7,6 \pm 0,3^{*}$ \\
\hline НСТ-тест спонтанний, \% & $8,0 \pm 0,3$ & $21,3 \pm 1,6^{*}$ & $33,3 \pm 2,8^{*}$ \\
\hline НСТ-тест стимульований, \% & $30,0 \pm 0,1$ & $21,9 \pm 2,7 *$ & $38,8 \pm 2,2 *$ \\
\hline Тлф, \% & $69,5 \pm 3,1$ & $74,4 \pm 2,3$ & $66,5 \pm 3,5$ \\
\hline $\mathrm{Th}, \%$ & $42,1 \pm 1,4$ & $56,8 \pm 1,9 *$ & $51,1 \pm 4,5^{*}$ \\
\hline Ts, $\%$ & $29,6 \pm 0,8$ & $17,1 \pm 2,8^{*}$ & $16,2 \pm 2,7 *$ \\
\hline $\mathrm{Th} / \mathrm{Ts}$ & 1,5 & $3,3^{*}$ & $3,2^{*}$ \\
\hline РБТЛ (РНА), \% & $56,0 \pm 0,9$ & $47,6 \pm 4,4$ & $32,8 \pm 2,7^{*}$ \\
\hline Влф, \% & $9,5 \pm 0,6$ & $11,2 \pm 1,4$ & $11,3 \pm 0,7$ \\
\hline Титр (CH's0) комплемента & $46,1 \pm 0,1$ & $42,2 \pm 2,1$ & $64,8 \pm 6,5^{*}$ \\
\hline $\operatorname{IgA}$, Г/л & $1,86 \pm 0,09$ & $2,07 \pm 0,22$ & $3,04 \pm 0,24^{*}$ \\
\hline IgM, г/л & $1,00 \pm 0,09$ & $1,98 \pm 0,17^{*}$ & $1,29 \pm 0,11^{*}$ \\
\hline $\mathrm{IgG}$, г/л & $9,87 \pm 0,26$ & $10,68 \pm 0,27^{*}$ & $12,12 \pm 0,26^{*}$ \\
\hline ЦІК, од. опт щ. & $0,60 \pm 0,04$ & $0,93 \pm 0,05^{*}$ & $1,06 \pm 0,08^{*}$ \\
\hline
\end{tabular}




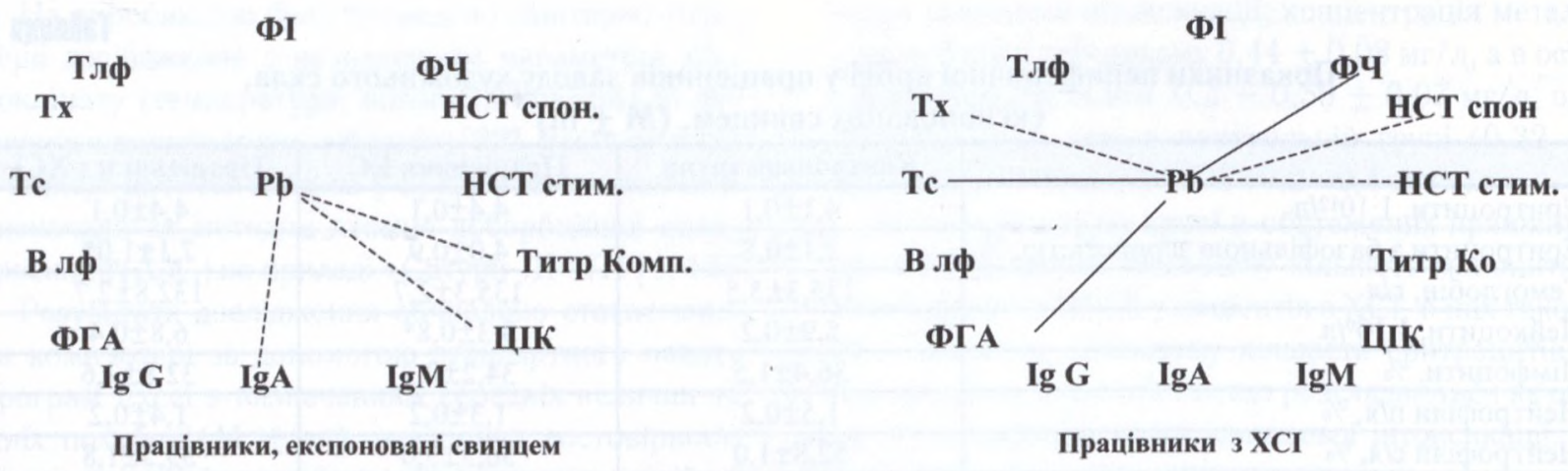

Рис. 1. Кореляційні зв'язки між показниками імунного статусу працівників ЗХС та вмістом Рь у крові.

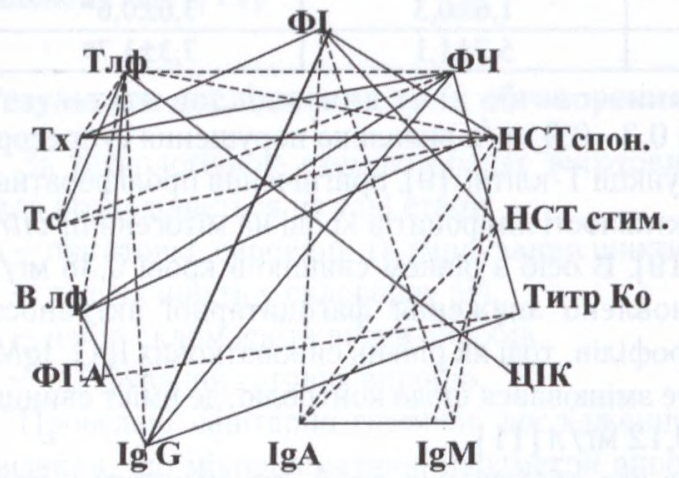

Працівники, експоновані свинцем

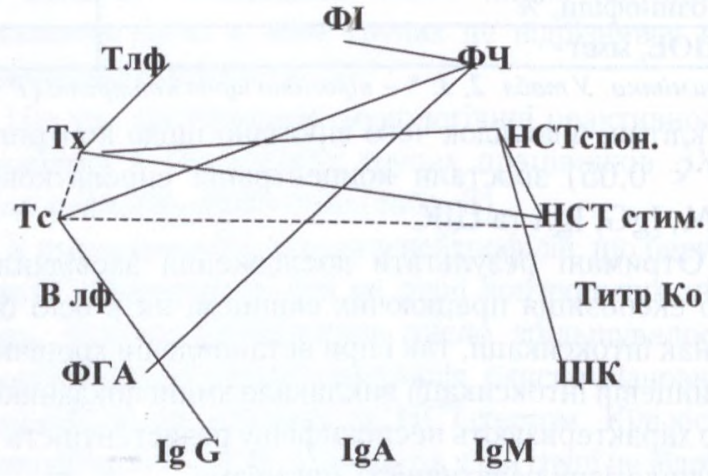

Працівники 3 XCI

Рис. 2. Кореляційні зв'язки між показниками імунного статусу організму працівників ЗХС.

Примітка:- позитивна кореляція $(r>0,5) ;------$ негативна кореляція $(r>-0,5)$.

Наслідки негативної дії свинцю на організм автори робіт $[5,16,23]$ пов'язують з його прооксидантними властивостями (стимуляція утворення вільних радикалів та перекисне окиснення ліпідів) та мембраноушкоджуючим ефектом.

Використання парного кореляційного аналізу для обробки отриманих нами результатів дослідження дало змогу встановити наявність різних за силою та спрямованістю кореляційних зв'язків між вмістом катіонів свинцю у крові обстежених працівників 3ХС та показниками неспецифічної резистентності й імунологічної реактивності їхнього організму. При цьому кількість зв'язків $(\mathrm{r}>0,5)$ була більшою в осіб з ХCI (рис. 1). Аналіз кореляційних зв'язків між імунологічними показниками в обстежених групах засвідчив, що вони були більш численними у групі робітників ЕС, ніж з ХСI (рис. 2). На нашу думку, наведені дані можуть бути свідченням того, що експозиція свинцем i, особливо, розвиток свинцевої інтоксикації у працюючих призводить до порушення взаємозв'язків між компонентами імунної системи з наступним дисбалансом та розвитком вторинного імунодефіцитного стану.

\section{Висновки}

1. У працівників заводу художнього скла, експонованих свинцем, без ознак інтоксикації та $з$ діагнозом хронічна свинцева інтоксикація виявлено зміни неспецифічної резистентності та специфічної імунологічної реактивності, що зумовлено негативною дією свинцю на організм.

2. В осіб з хронічною свинцевою інтоксикацією спостерігали порушення майже всіх показників імунного статусу, що корелювали з вмістом свинцю в крові. У працівників без ознак інтоксикації виявлені зміни були схожі за спрямованістю, проте менш виражені.

3. Встановлені порушення показників неспецифічної резистентності (стимуляція поглинаючої активності нейтрофілів, окисно-відновних процесів в них) та імунологічної реактивності (порушення співвідношення імунорегуляторних клітин $\mathrm{Th} / \mathrm{Ts}$, підвищений синтез імуноглобулінів з утворенням імунних комплексів) у працівників, експонованих свинцем, можуть бути зумовлені мембранотоксичними та прооксидантними властивостями цього металу i свідчать про формування вторинного імунодефіциту. 


\section{Література}

1. Асылбекова Ж.З. Состояние иммунологических показателей у больных сатурнизмом//Респ. конф. "Актуальные вопросы гигиены труда, токсикология и профессиональная патология в цветной металлургии»: Тез. докл.-Алма-Ата, 1980.- С.78-79.

2. Галицкий Я.Д. Усовершенствование определения иммуноглобулинов методом радиальной иммунодиффузии в геле//Лабор. дело, 1987.- №12.- С. 925-927.

3. Дмитруха Н.М. Експериментальне дослідження впливу важких металів (свинцю та кадмію) на неспецифічну резистентність організму білих щурів/ / Соврем. пробл. Токсикоз.- 2004.- №4.- С. 27-31.

4. Dobrovolsky L., Vitte P., Belashova I. et al. Blood lead monitoring studies in Chernobyl region in 1992//Abstr. Eight Int. Symp. on Trace Elements in Man and Animals. Tema 8, May 1993.- Dresden: Townholl Abstracts, 1993.- P. 140.

5. Забродский П.Ф. Механизмы токсического действия металлов и их влияние на иммунную систему/ /Токсикол. вестн.- 1998.- №6.- С. 6-9.

6. Измеров Н.Ф. К проблеме оценки воздействия свинца на организм человека//Мед. труда и пром. экол.- 1998.- №12.- С. 1-4.

7. Immunotoxicology/A.Berlin, J.Dean, M.N.Draper et al.- Geneva, 1987.-495 p.

8. Immunotoxicity of metals and immunotoxicology. Proceedings of an International Workshop/Ed. by A.D.Deyan, R.F.Yertel, E.Heseltine et al.- New York, London: Plenum press, 1990.-316 p.

9. Cohén N., Modai D. et al. Increased concanavalin Ainduced suppressor cell activity in humans with occupational lead exposure//Environ. Res.- 1989.-V.48.- P. 1-6.

10. Jaremin B. Blast lymphocyte transformation (LTT), rosette (E-RFC) and leukocyte migration inhibition (MIF) tests in persons exposed to the action of lead during work//Report II Bull. Inst. Mar. Trop. Med (Gdynia).- 1983.- №34.- P. 187-197.

11. Kimber I., Stonard M.D., Gidlow D.A., Niewola Z. Influence of chronic low level exposure to lead on plasma immunoglobulin concentration and cellular immune function in man//Int. Arch. Occup. Environ. Health.- 1986.- V.57.- P. 117-125.

12. Корбакова А.И., Сорокина Н.С., Молодкина Н.Н. и др. Свинец и его действие на организм/ /Мед. труда и пром. экол.- 2001.- №5.- С. 29-33.

13. Lawrence D.A., Mudzinsky S., Rudofsky U. Warner Mechanisms of metal induced immunotoxicity in Immunotoxicology/Ed. by A.Berlin, J.Dean, M.N.Draper et al.- 1987, P. 293-303.

14. Минцер Е.У., Угаров О.П., Власов В.В. Методы обработки медицинской информации.- К.: Вища шк., 1991.-271 с.

15. Методические указания по измерению вредных веществ в воздухе.- М., 1986.- Вып.21.- С. 168-171.

16. Общая токсикология/Под ред. Б.А.Курляндского, В.А.Филова.- М.: Медицина, 2002.- 608 с.
17. Паранько Н.М., Рублевская Н.И. Гигиеническая характеристика загрязнения тяжелыми металлами окружающей среды промышленного региона и иммунный статус детей//Гиг. и сан.- 1999.- №2.- С. 51-54.

18. Пастер Е.У., Овод В.В., Позур В.К. Иммунология.- К.: Вища шк., 1989.- 284 с.

19. Sata Fumihiro et al. Changes in T cells subpopulations in lead workers//Environ. Res.- 1998.- №1.P. 61-64.

20. Сепиашвили Р.И. Введение в иммунологию.Цхалтубо-Кутаиси, 1987.- 230 с.

21. Справочник: Лабораторные методы исследования в клинике/Под ред. В.В.Меньшикова.- М.: Медицина, 1987.- 368 с.

22. Справочник по гигиене труда/Под ред. Б.Д.Карпова, В.Е.Ковшило.- М.: Медицина, 1979.

23. Соломенчук Т.Н., Холін С.Є. Перекисне окислення ліпідів в осіб з артеріальною гіпертензією, які працюють у контакті з аерозолем свинцю/ /Укр. кардіол. журн.- 1996.- №5-6.- С. 77-78.

24. Стежка В.А., Дмитруха Н.Н., Покровская Т.Н. и др. Влияние соединений тяжелых металлов из окружающей среды на состояние иммунной системы у механизаторов сельского хазяйства//Довкілля та здоров'я.- 2002.- №1(20).- С.6-11.

25. Столяров И.Д., Огурцов Р.П., Петров А.М. и др. Коррекция миелопидом иммунодефицита у сотрудников промышленного предприятия, работающих со свинецсодержащими материалами//Мед. труда и пром. экол.- 2001.- №5.- С. 26-34.

26. Токмурзаев М., Рекун И. Влияние свинца на образование активных форм кислорода при фагоцитозе//Вопросы гигиены, физиологии труда и профпатологии в связи с научно-техническим прогресcoм.- M., 1986.- C. 54-55.

27. Toxicological Profile for Lead. Draff for Public Comment/ /Comment Period Ends: February 17, 1998.483 p.

28. Трахтенберг И.М., Луковенко В.П. Тяжелые металлы как потенциально токсичные химические вещества и загрязнители производственной и окружающей среды.- К.: Знание, 1990.- 19 с.

29. Трахтенберг И.М. Тяжелые металлы как химические загрязнители производственной и окружающей среды/ / Довкілля та здоров’я.- 1997.- №2.- С. 48-51.

30. Тулубеев Р.К., Панкова В. Б. Состояние респираторного тракта и иммунного статуса у больных сатурнизмом//Вест. оториноларингол.- 1995.- №1.С. 34-37.

31. Хаитов Р.М., Пинегин Б.В., Истамов Х.И. Экологическая иммунология.- М.: ВНИРО, 1995.- 219 с.

32. Чернушенко Е.Ф. Диагностика вторичных иммунодефицитных состояний//Журн. практ. лікаpя.- 2000.- №1.- С. 6-10.

33. Узарбаєва Р.Е. Влияние свинцовой интоксикации на алергию немедленного типа//Пигиена труда и проф. забол.- 1986.- №8.- С. 50-51. 


\section{Амитруха Н.Н., Короленко Т.К., АнАрусишина И.Н. СОСТОЯНИЕ ИММУННОЙ СИСТЕМЫ У РАБОТАЮШИХ, ЭКСПОНИРОВАННЫХ СвИНЧОМ}

Институт меАишины труда АМН Украины, г. Киев

В работе представлены результаты исследования состояния иммунной системы организма работников завода художественного стекла, экспонированных свинцом. По данным биомониторинга, содержание катионов свинца в крови обследованных превышало нормативные значения. У лиц с диагнозом хроническая свинцовая интоксикация $(\mathrm{Pb}-0,59 \pm 0,07$ мг/л) наблюдались нарушения почти всех клеточных и гуморальных показателей иммунного статуса, которые коррелировали с концентрацией свинца в крови. У работающих с содержанием свинца на уровне $0,44 \pm 0,08$ мг/л, без признаков интоксикации выявленные изменения были схожими по направленности, но менее выраженными.

Ключевые слова: иммунная система, свинец, интоксикация

\section{Dmytrukha N.M., Korolenko T.K., Andrusyshyna I.M.}

\section{STATE OF IMMUNE SYSTEM IN WORIKERS EXPOSURED TO LEAD}

\section{Institute for Occupational Health of AMS of Ukraine, Kyiv}

This paper presents the results of research of the state of immune system in glass factory workers exposured to lead. The blood lead level in examined persons was higher than the available values by the biomonitoring data. Persons with a diagnosis of chronic lead intoxication $(\mathrm{Pb}-0.59 \pm 0.07 \mathrm{mg} / \mathrm{l})$ had significant disorders of cellular and humoral immunity which correlated with the lead concentration in blood. Workers with lead content in blood of $0.44 \pm 0.08 \mathrm{mg} / 1$ and without signs of intoxication had similar changes by direction, but less expressive.

Key words: immune system, lead, intoxication

Надійшла 10.03.2006

Контактна особа: Дмитруха Наталія Миколаївна, Інститут медицини праці АМН України, Київ, 01033, вул. Саксаганського, 75, тел. служ. (044) 289-51-85, тел. дом. (044) 249-84-49, e-mail: Dmytrukha@ukr.net 